\title{
Pensares em Revista: um relato sobre estratégias que auxiliaram na evolução do periódico
}

Maria Betânia Almeida Pereira, Brígida Gabriela Vieira de Carvalho, Débora de Freitas Ferreira

Pensares em Revista, periódico eletrônico do Programa de Pós-Graduação em Letras - o PROFLETRAS - da Faculdade de Formação de Professores, da Universidade do Estado do Rio de Janeiro (FFP-UERJ). A revista integra o Portal de Publicações da UERJ, sendo assim institucional e de acesso aberto, fazendo uso do sistema OJS. Por meio de dados, comprovamos a importância da divulgação e da utilização das redes sociais para a manutenção do acesso aberto e gratuito ao conhecimento científico. Somos um periódico que oferece acesso livre aos artigos publicados em sua plataforma, como uma maneira de incentivar a disseminação do conhecimento científico na área de Letras, a fim de que a informação se torne democratizada.

Já havíamos iniciado um trabalho de divulgação da revista e de seu conteúdo na plataforma do Facebook, todavia o investimento em redes sociais foi intensificado. Estratégias de engajamentos em eventos, a utilização do Instagram como meio de divulgação dos artigos e chamadas têm feito com que o periódico avance consideravelmente em seu nível de visualização.

Já havíamos iniciado um trabalho de divulgação da revista e de seu conteúdo na plataforma do Facebook, todavia o investimento em redes sociais foi intensificado. Estratégias de engajamentos em eventos, a utilização do Instagram como meio de divulgação dos artigos e chamadas têm feito com que o periódico avance consideravelmente em seu nível de visualização. Podemos elencar alguns avanços consideráveis: a avaliação B1 pela Qualis Capes. Avançou no quadro de uma revista semestral para uma revista quadrimestral. Além disso, houve aumento no número de acessos ao site, conforme dados do sistema OJS. No ano de 2014 o número de acesso aos textos era de 2.076 e, em setembro de 2018 , já atingia 13.368 .
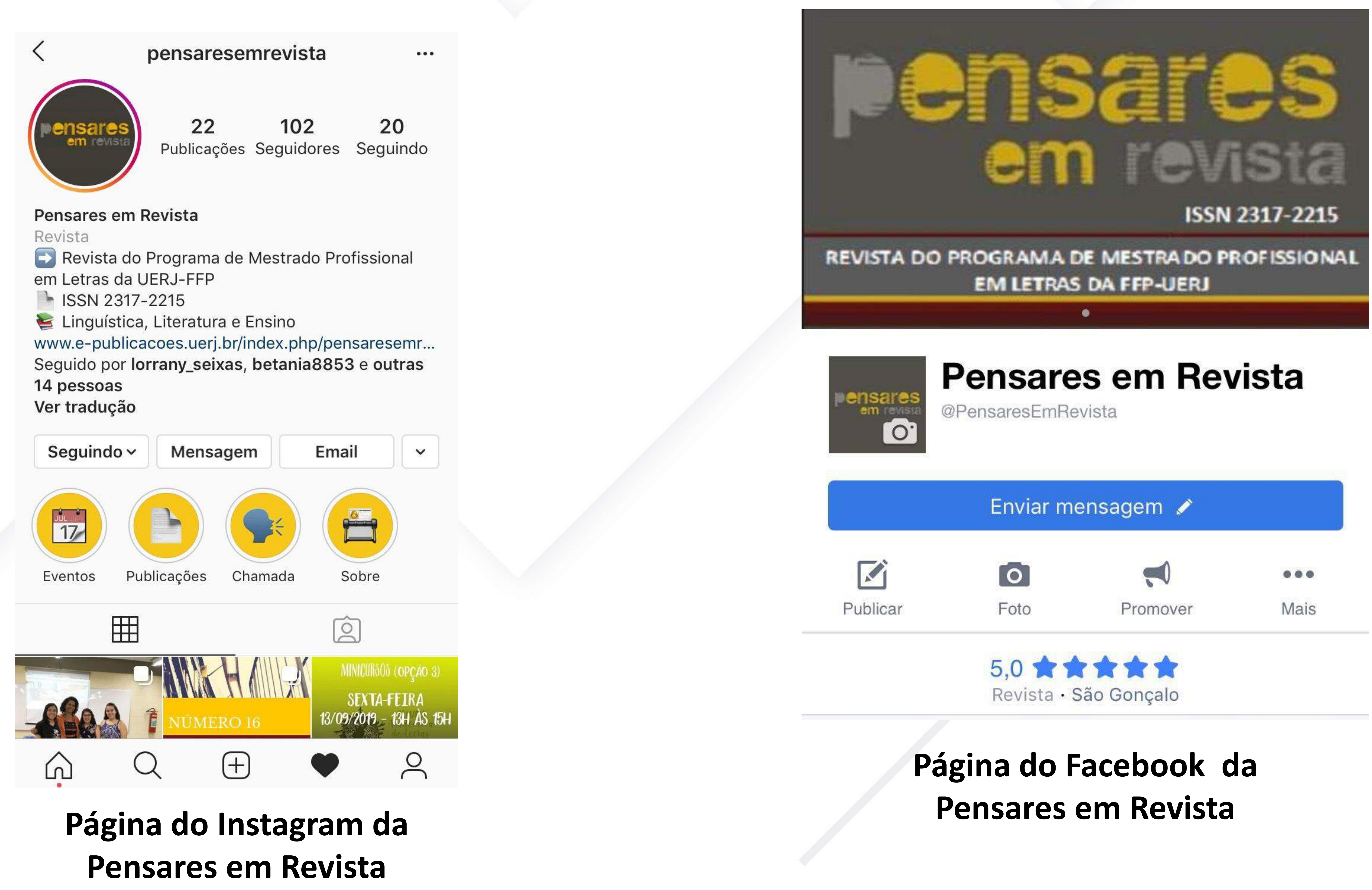

Página do Facebook da Pensares em Revista

Segundo o Google Analytics ocorreu um aumento significativo no número de visualizações e de usuários. Em 2016,foi 29.647 e em setembro de 2018 atingiu 77.078, bem como o número de usuários que de 2016 para setembro de 2018 passou de 4.139 para 9.604. Verificou-se acessos por 10 países. Em informações capturadas pela ferramenta digital Gyazono mês de setembro de 2018, pôde ser identificada a porcentagem de usuários por país, gerando os seguintes resultados: $92 \%$ no Brasil; 1,31\% no Reino Unido; 1,31\% nos Estados Unidos; 0,85\% em Portugal; 0,48\% na Índia; 0,43\% no Peru; 0,43\% no Senegal; 0,29\% na Itália; 0,29\% na Alemanha e 0,20\% na Argentina.

Conquistas da revista, como as avaliações positivas e o aumento no número de acessos, são um grande incentivo para nós editoras continuarmos investindo em estratégias de divulgação e crescimento. 